\title{
Consumption as the main element of the reproduction process in agriculture
}

\author{
Maria Tyapkina* \\ Irkutsk State Agrarian University named after A. A. Ezhevskiy, 664038 Irkutsk, Russia
}

\begin{abstract}
One of the criteria for ensuring food security is the consumption of basic food products per capita, which characterizes the level and quality of life. Food consumption is the result of the reproductive process in agriculture. The article discusses the level of self-sufficiency on the materials of the Irkutsk region, is compared with the food security criteria provided for in the Doctrine. All food products, except for potatoes, residents of the Irkutsk region consume significantly less, compared with residents of the Russian Federation. For meat, milk, egg, vegetables, consumption does not meet the rational standards recommended by the Ministry of Health for a healthy diet. A regression model of the relationship between per capita incomes of the country and milk consumption per capita is presented. The mismatch between the excessive content of fat in food, potatoes, sugar and bread in the diet and the lack of calorie intake affects the health of the population of the Irkutsk region. It is necessary to achieve the level of production of the main types of high-quality food products, enough to provide the population of the Irkutsk region and reduce food dependence.
\end{abstract}

\section{Introduction}

Being the final phase of the reproduction process, consumption serves as a prerequisite for the formation of a new reproductive cycle and is the result of the reproductive process.

\section{Problem statement}

Indicators of food consumption are among the most important characteristics of the level and quality of life of the population, are included in the system of general indicators of socio-economic development of any country and are an integral basis of human life. The quality and structure of consumed food products affect the health status of the country's population, determining its economic and food security.

After the introduction of retaliatory restrictive measures in foreign trade by the Russian Federation, the food problem worsened when about a fifth of the total volume of Russian imports of food products and agricultural raw materials for its production fell under foreign sanctions, which corresponds to almost $15 \%$ of their domestic consumption [1].

The imposition of foreign sanctions following the reunification of Crimea with Russia and the outbreak of the Ukrainian crisis exacerbated the problems of reliable food supply to the country.

\section{Purpose of the study}

Assess the consumption of basic foodstuffs in the Irkutsk region and the achievement of the criteria provided for in the Doctrine of Food Security and the recommended norms of consumption for a full and healthy lifestyle.

\section{Research questions}

One of the criteria for ensuring food security is the consumption of basic foodstuffs per capita, which in our region has not reached a rational norm.

The region fully provides itself with poultry meat (30 kg), eggs (191 pcs.), and potatoes (121 kg). However, the level of self-sufficiency of the population of the Irkutsk region in agricultural products in 2017 amounted to $64.1 \%$ for meat, $87.2 \%$ for milk, and $58.4 \%$ for vegetables. In accordance with the Doctrine of Food Security of the Russian Federation - 2010, the necessary level of self-sufficiency should be $85.0 \%$ for meat, $90 \%$ for milk, $90 \%$ for vegetables, $95 \%$ for grain.

The Ministry of Agriculture of Russia has developed a draft new Doctrine of Food Security in Russia, which includes an indicator of economic affordability of food, which reflects the possibility of the population acquiring food at current prices in enough quantity and assortment within the framework of established consumption standards.

Corresponding author: mft74@mail.ru 
Also, the Doctrine will consider the physical accessibility of products, that is, the sufficiency of providing the population with objects of trade. As a result, the methodology for calculating indicators is changing, where food security in the country will be assessed not by the share of domestic production, but by the degree of satisfaction of domestic market needs at the expense of domestic production.

Table 1. The level of self-sufficiency in products in the Irkutsk region for the period $2005-2017, \%$

\begin{tabular}{|c|c|c|c|}
\hline $\begin{array}{c}\text { Type of } \\
\text { product }\end{array}$ & $\mathbf{2 0 0 5}$ & $\mathbf{2 0 1 0}$ & $\mathbf{2 0 1 7}$ \\
\hline meat & 58.7 & 58.6 & 64.1 \\
\hline milk & 94.2 & 86.1 & 87.2 \\
\hline egg & 175.7 & 167.1 & 162.5 \\
\hline potatoes & 93.4 & 105.4 & 88.7 \\
\hline vegetables & 74.3 & 75.8 & 58.4 \\
\hline
\end{tabular}

Table 2. Food Security Criteria for the Doctrine

\begin{tabular}{|c|c|}
\hline $\begin{array}{c}\text { The value at which food } \\
\text { security is achieved }\end{array}$ & Type of product \\
\hline $\begin{array}{c}\text { Greater than or equal to } \\
80\end{array}$ & $\begin{array}{c}\text { sugar, vegetable oil, fish } \\
\text { products }\end{array}$ \\
\hline $\begin{array}{c}\text { greater than or equal to } \\
85\end{array}$ & $\begin{array}{c}\text { meat and meat products, food } \\
\text { salt }\end{array}$ \\
\hline $\begin{array}{c}\text { greater than or equal to } \\
90\end{array}$ & milk and dairy products \\
95 & grain, potatoes \\
\hline $\begin{array}{c}\text { greater than or equal to } \\
95\end{array}$
\end{tabular}

For goods exceeding 100 percent, the export potential will be calculated. Updating the Doctrine is associated with the emergence of new risks and threats to food security caused by economic sanctions,

Table 3. The level of food dependence of the Irkutsk region

\begin{tabular}{|l|c|c|c|}
\hline \multicolumn{3}{|c|}{ meat and meat products } \\
\hline Production, thousand tons & 2005 & 2010 & 2017 \\
\hline import, including import, thousand tons & 58.3 & 66.9 & 73.6 \\
\hline share of import to production, \% & 74.2 & 75.7 & 70.8 \\
\hline \multicolumn{4}{|c|}{ milk and dairy products } \\
\hline Production, thousand tons & 489.2 & 451.1 & 458.0 \\
\hline import, including import, thousand tons & 37.5 & 82.2 & 97.5 \\
\hline share of import to production, \% & 7.7 & 18.2 & 21.3 \\
\hline \multicolumn{4}{|c|}{ eggs and egg products } \\
\hline Production, thousand tons & 817.6 & 905.3 & 1009.7 \\
\hline import, including import, thousand tons & 38.0 & 41.0 & 72.1 \\
\hline share of import to production, \% & 4.6 & 4.5 & 7.1 \\
\hline \multicolumn{4}{|c|}{ corn } \\
\hline Production, thousand tons & 645.0 & 554.3 & 871.6 \\
\hline import, including import, thousand tons & 59.0 & 47.5 & 36.0 \\
\hline share of import to production, \% & 9.1 & 8.6 & 4.1 \\
\hline \multicolumn{4}{|c|}{ potatoes } \\
\hline Production, thousand tons & 594.8 & 632.9 & 397.3 \\
\hline import, including import, thousand tons & 0.3 & 0.4 & 7.1 \\
\hline share of import to production, \% & 0.05 & 0.06 & 1.79 \\
\hline \multicolumn{4}{|c|}{ vegetables } \\
\hline Production, thousand tons 130.7 & 153.3 & 107.3 \\
\hline import, including import, thousand tons & 42.8 & 45.8 & 75.9 \\
\hline share of import to production, \% & 32.7 & 29.9 & 70.7 \\
\hline
\end{tabular}

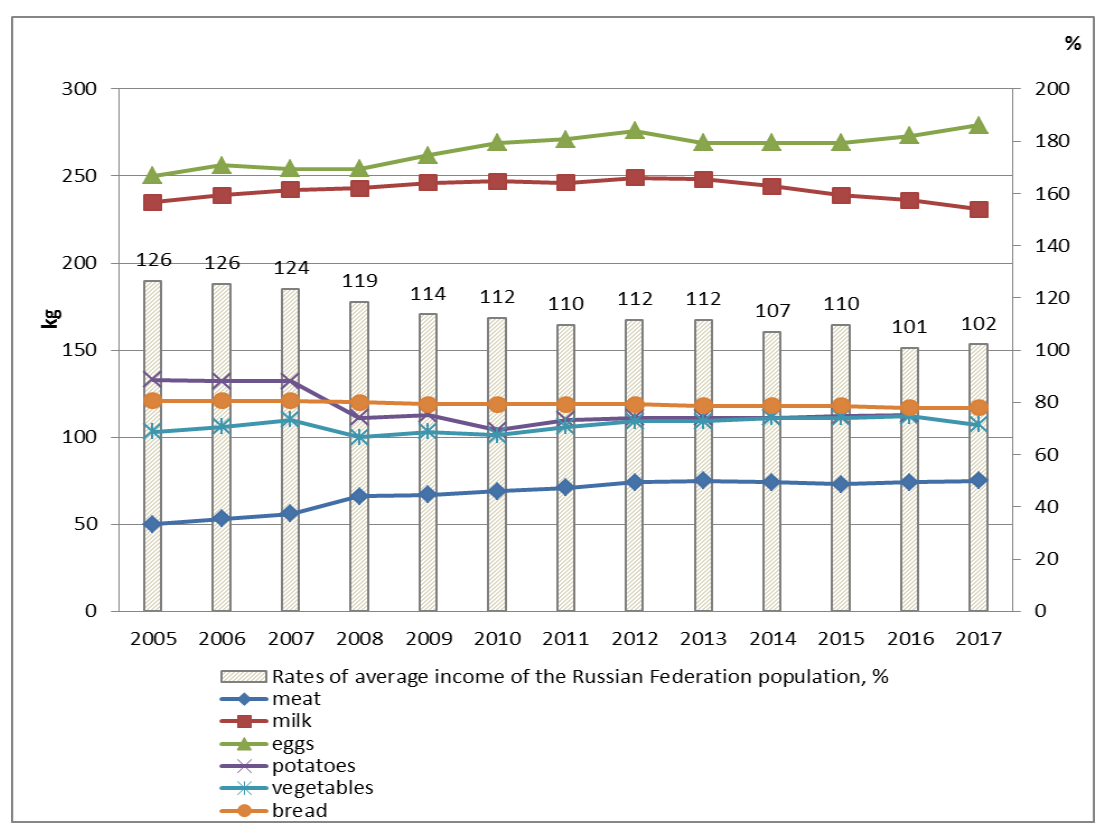

Fig. 1. Dynamics of incomes per capita and food consumption in the Russian Federation for 2005-2017.

Russia's entry into the WTO and the deepening of integration processes within the EAEU. The main volumes of import substitution will be required in the production of beef meat, milk, cheese, butter, vegetables, open and closed ground, food wheat [2].
Criteria of food independence were achieved in the Irkutsk region for grain, potatoes, and eggs, except milk, meat and vegetables. Indicators of import dependence improved due to an increase in production of meat, egg and grain. During the analyzed period, imports, 
including imports to the region, increase, except for grain.

Incomes per capita are growing in dynamics, as they are presented at current prices and it is difficult to assess the impact on the possibility of improving the nutrition of the population.

Each year, each resident of the Russian Federation consumed an average of 67 kilograms of meat and meat products, $242 \mathrm{~kg}$ of milk and milk products, $265 \mathrm{eggs}$, $115 \mathrm{~kg}$ of potatoes, $107 \mathrm{~kg}$ of vegetables, $119 \mathrm{~kg}$ of bread products (flour, cereals, legumes, pasta), $39 \mathrm{~kg}$ of sugar and $13.3 \mathrm{~kg}$ of vegetable oil. In 2017, the country's inhabitants consumed 75 kilograms of meat and meat products ( $11 \%$ higher than average), $231 \mathrm{~kg}$ of milk and milk products ( $5 \%$ lower than average), 279 eggs (5\% higher than average), and $96 \mathrm{~kg}$ of potato (16\% lower than average), $107 \mathrm{~kg}$ of vegetables (no change), $117 \mathrm{~kg}$ of bread products (no change), $39 \mathrm{~kg}$ of sugar (5\% higher than average) and $13.9 \mathrm{~kg}$ of vegetable oil (2\% lower than average). It should be noted that the structure of consumption is improving, the growth of vegetable

crops in 2017 compared to 2005 by $4 \%$ and a decrease in potatoes by $28 \%$, bread $-3 \%$.

Based on the regression model between the average income per capita of the country's population (x1) and milk consumption per capita $\left(\mathrm{y}_{\mathrm{x}}\right)$, the following dependence was manifested - with an increase in the average per capita income of the population by 1 ruble. milk consumption increases by $0.07 \mathrm{~kg}$. The relationship between the studied factors is direct and close, which is confirmed by the significance of the correlation coefficients (multiple correlation coefficient 0.83, determination coefficient 0.69 , the regression equation has the form: $y=226+0.07 x$ ).

The standard error of the regression equation is: $\sigma_{\mathrm{y}}=$ 2.9 , the evaluation of the quality of the parameters of the regression equation by the Fisher criterion showed that the regression equation is significant, since $F \varphi=54$ significantly exceeds the table value $\mathrm{F}_{\mathrm{T}}=1.96$. Assessment of the significance of the coefficients using Student's t-test $\mathrm{t}_{\text {calc }}=78>\mathrm{t}_{\text {table }}=2.1$ at a significance level of $\alpha=95 \%$ shows that the coefficients of the equation are significant.

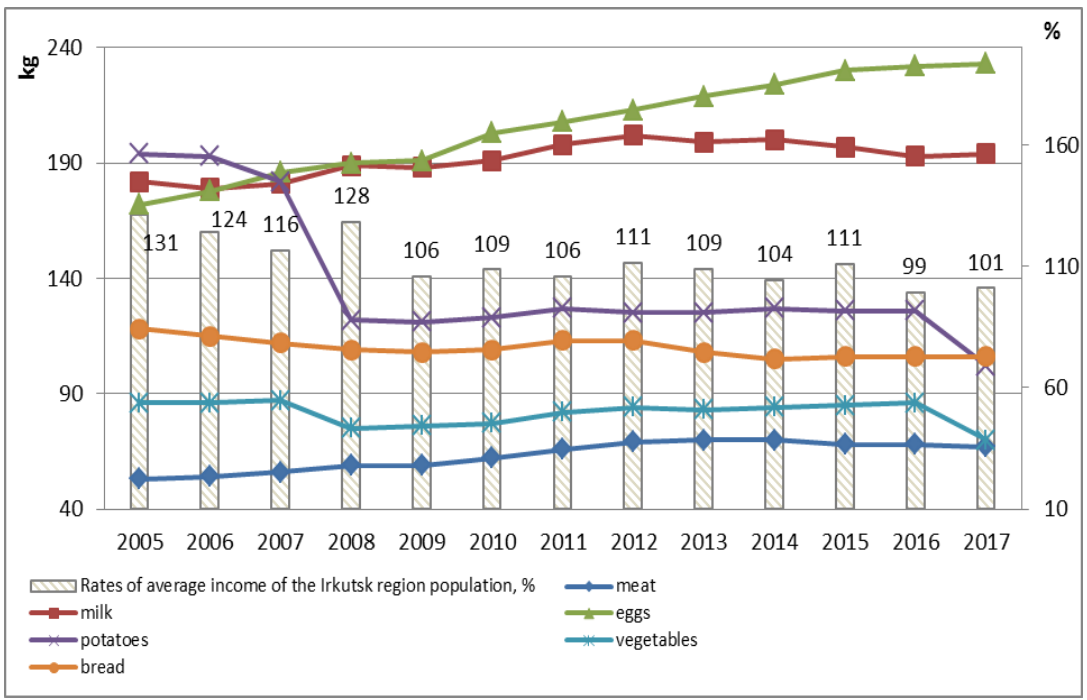

Fig. 2. Dynamics of incomes per capita and food consumption in the Irkutsk region for 2005-2017.

Each year, every resident of the Irkutsk region consumed an average of $63 \mathrm{~kg}$ of meat and meat products, $192 \mathrm{~kg}$ of milk and dairy products, $206 \mathrm{eggs}$, $138 \mathrm{~kg}$ of potatoes, $82 \mathrm{~kg}$ of vegetables, $110 \mathrm{~kg}$ of bread products (flour, cereals, legumes, pasta), $32 \mathrm{~kg}$ of sugar and $12.4 \mathrm{~kg}$ of vegetable oil. In 2017, the population in the region consumed 67 kilograms of meat and meat products (6\% higher than the average), $194 \mathrm{~kg}$ of milk and milk products (1 \% higher than the average), 233 eggs (13\% higher than the average), $102 \mathrm{~kg}$ of potatoes (26\% lower than the average), $70 \mathrm{~kg}$ of vegetables (14\% lower than average), $106 \mathrm{~kg}$ of bread products (4\% lower than average), $31 \mathrm{~kg}$ of sugar (4\% lower than average) and $12.7 \mathrm{~kg}$ of vegetable oil (3\% higher than average).

For products such as milk, egg, meat, there is a tendency to increase consumption by the population of the Irkutsk region. All food products, except for potatoes, residents of the Irkutsk region consume significantly less, compared with residents of the Russian Federation. So, meat is consumed less by an average of $6 \%$ over the period, and by $11 \%$ in 2017 ; there is less milk on average for the period by $21 \%$, and for 2017 - by $16 \%$; eggs are less on average over the period by $22 \%$, and in 2017 - by $16 \%$; less vegetables on average for the period by $24 \%$, and in 2017 - by $35 \%$; sugar is lower on average for the period by $18 \%$, and in 2017 - by $21 \%$; vegetable oil is less on average for the period by $7 \%$, and in 2017 - by $9 \%$; There is less bread on average over the period by $8 \%$, and in 2017 - by $9 \%$, only potatoes consume more on average by $20 \%$, and in 2017 - by $6 \%$.

Secured consumption of agricultural products is carried out through own production and import from other constituent entities of the Russian Federation and import into the region of about $36 \%$ of meat, $13 \%$ of milk, $42 \%$ of vegetables, and potatoes $11 \%$ in 2017 [3]. 
Table 4. Comparison of food consumption in the Irkutsk region with the Russian Federation

\begin{tabular}{|c|c|c|}
\hline $\begin{array}{c}\text { Type of } \\
\text { product }\end{array}$ & $\begin{array}{c}\text { Consumption in the } \\
\text { Irkutsk region with } \\
\text { the Russian } \\
\text { Federation (average } \\
\text { values 2005-2017) }\end{array}$ & $\begin{array}{c}\text { Consumption in the } \\
\text { Irkutsk region with } \\
\text { the Russian } \\
\text { Federation in 2017 }\end{array}$ \\
\hline Meat & 0.94 & 0.89 \\
\hline Milk & 0.79 & 0.84 \\
\hline Eggs & 0.78 & 0.84 \\
\hline Potatoes & 1.2 & 1.06 \\
\hline Vegetables & 0.76 & 0.65 \\
\hline Sugar & 0.82 & 0.79 \\
\hline oil rust. & 0.93 & 0.91 \\
\hline bread & 0.92 & 0.91 \\
\hline
\end{tabular}

At the World Food Summit in Rome, the definition of food security was introduced, which understood the situation that the government of each country should strive for, when each of its inhabitants has physical and economic access to safe food enough for an active and fulfilling life. It was implied that not in all cases this access should be provided at the expense of national production. Governments must ensure the security of supply, and the population should be able to buy it in volumes enough for a full and healthy lifestyle.

The FAO methodology considers:

- availability of products to meet food needs; within the framework of this, the possibilities of own production, losses, stocks, imports, etc. are considered;

- economic and physical accessibility to food of the proper volume and quality, of all social groups (the ability to buy food in the right amount and reach the place where it is sold);

- stability of food supply, including analysis of changes in prices and production volumes; social conflicts should also be monitored, in which there is always a decline in food security in order to respond in a timely manner to what is happening;

- food consumption from the standpoint of nutrition in calories, protein, trace elements, etc .; it also considers the spread of obesity as a result of an unbalanced diet, the spread of anemia, stunted growth, etc.

Monitoring of food security in the world in 2017 confirmed the persistence of many problems, some of which are not critical for our country, but in 2014-2017. against the backdrop of a slowdown in economic development, food access for the poor has narrowed [4].

The Economist Intelligence Unit (EIU) has calculated the Global Food Security Index (GFSI) since 2012 for 113 countries. When calculating the Global Index, 28 main and 8 additional indicators are used, which are divided into three groups:

- availability and consumption of food;

- availability and sufficiency of food;

- food safety and quality and dietary diversification.

Food Security Index of Russia in 2013-2016 decreased relative to 2012, but in 2017 growth was recorded almost to the level of 2012. Among 113 countries, Russia fell from 39th to 48th place in this index (by 2015-2016), then rose to 41. Improving the global the index was due to the index "availability and sufficiency of consumption" - moving up 19 positions among 113 countries, the index of "accessibility and level of consumption" - by 4 positions, the index of food quality and safety - by one position.

However, the level of 2013 was not achieved. Obviously, given the growth in agricultural production and the lack of food shortages in stores, Russia's transition to a lower position compared to 2013 is due to other factors [5]. As can be seen from the analysis of individual indicators that form these three parts of the Global Index, the decrease was due to insufficient funding for research, a reduction in product diversity, as well as political risks and corruption in 2013-2016 [6].

The Doctrine of Food Security (2010) presents a system of indicators for monitoring food security in the Russian Federation. The system was approved by Order of the Government of the Russian Federation and includes four groups of targets:

- rational food consumption standards (per person per year), approved by the Ministry of Health;

- physiological requirements for energy and nutrients (per person per day) approved by the Federal Service for Supervision of Consumer Rights Protection (energy, protein, fats, carbohydrates, minerals, vitamins);

- threshold values of food independence for individual products (the share of domestic products in commodity resources), approved in the Doctrine of Food Security;

- standards for the provision of commodity space for the population of the constituent entities of the Federation (in meters per 1000 people), approved by the Ministry of Industry.

The Order proposes to use for monitoring a total of about six hundred indicators at the federal level and at the level of each subject of the Federation. Analysis and formulation of conclusions on the state of food security based on such many indicators is very difficult, therefore, official publications / statements on food security are based on a limited number of indicators: production, import-export, consumption [7]. In a rare number of cases, an indicator characterizing the share of household spending on food is provided.

Table 5. Consumption of basic food products in the Irkutsk region for 2005-2017 and dietary compliance with recommended standards (kg per person per year)

\begin{tabular}{|c|c|c|c|c|}
\hline Type of product & 2005 & 2010 & 2017 & $\begin{array}{c}\text { Rational } \\
\text { norms }\end{array}$ \\
\hline meat & 53 & 62 & 67 & 73 \\
\hline milk & 182 & 191 & 194 & 325 \\
\hline eggs & 172 & 203 & 233 & 260 \\
\hline potatoes & 194 & 123 & 102 & 90 \\
\hline vegetables & 86 & 77 & 70 & 140 \\
\hline sugar & 28 & 32 & 31 & 24 \\
\hline oil rust. & 11.6 & 11.7 & 12.7 & 12 \\
\hline bread & 118 & 109 & 106 & 96 \\
\hline
\end{tabular}


In the Irkutsk region, for such foods as meat, milk, eggs, vegetables, consumption does not meet the rational standards recommended by the Ministry of Health [8] for a healthy diet for the population. So, in 2017, meat consumption is $67 \mathrm{~kg}$, which is $6 \mathrm{~kg}$ lower than the norm (-8\%); milk $194 \mathrm{~kg}$, which is below the norm by $131 \mathrm{~kg}$ $(-40 \%)$; eggs 233 units, which is lower by 27 units $(-10 \%)$; vegetables $70 \mathrm{~kg}$, which is below the norm by $70 \mathrm{~kg}(-50 \%)$. Potato consumption is above the norm by $12 \mathrm{~kg}(+13 \%)$ and amounts to $102 \mathrm{~kg}$; sugar is above the norm by $7 \mathrm{~kg}(+29 \%)$ and amounts to $31 \mathrm{~kg}$ per year; vegetable oil is above the norm by $0.7 \mathrm{~kg}(+6 \%)$ and is $12.7 \mathrm{~kg}$; bread above the norm recommended for a healthy diet of $10 \mathrm{~kg}(+10 \%)$ and is $106 \mathrm{~kg}$ per year. In general, the dynamics are improving, for the analyzed period 2005-2017. consumption increases for meat by $26 \%$, milk $-7 \%$, egg $-35 \%$, sugar $-11 \%$, vegetable oil - $9 \%$, and decreases for potatoes by $47 \%$, vegetables by $19 \%$, bread by $10 \%$.

For vegetable oil, the recommended consumption rate is exceeded, but at the same time, the actual level of vegetable oil consumption in Russia is much lower than in developed countries. For example, its consumption in Russia is about $14 \mathrm{~kg}$ per year compared to $17 \mathrm{~kg}$ in Germany, $18 \mathrm{~kg}$ in the UK, $21 \mathrm{~kg}$ in France, $28 \mathrm{~kg}$ in Italy and $31 \mathrm{~kg}$ in the USA. In 2017, 5.7 million tons of vegetable oil were produced in Russia, a little more than 1 million tons were imported (of which 0.9 million tons are palm), 1.8 million tons were exported.

Table 6. International comparisons of basic food consumption (kg per person per year)*

\begin{tabular}{|c|c|c|c|c|c|c|}
\hline Type of product & 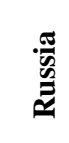 & & 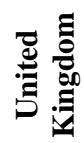 & 苞 & 㟔 & 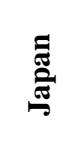 \\
\hline meat & 73 & 88 & 82 & 89 & 118 & 49 \\
\hline milk & 239 & 436 & 241 & 250 & 276 & 89 \\
\hline eggs & 269 & 233 & 191 & 227 & 263 & 305 \\
\hline potatoes & 112 & 78 & 101 & 55 & 56 & 21 \\
\hline vegetables & 111 & 93 & 94 & 104 & 113 & 92 \\
\hline sugar & 39 & 33 & 40 & 38 & 59 & 19 \\
\hline oil rust. & 13.6 & 15 & 18 & 21 & 31 & 13 \\
\hline bread & 118 & 103 & $\mathrm{n} / \mathrm{a}$ & $\mathrm{n} / \mathrm{a}$ & $\mathrm{n} / \mathrm{a}$ & 89 \\
\hline
\end{tabular}

Table 7. Nutritional value of the existing diet, g per day per family member in the Russian Federation for 2005-2017

\begin{tabular}{|c|c|c|c|c|}
\hline Indicator & Protein & Fats & $\begin{array}{c}\text { Carboh } \\
\text { ydrates }\end{array}$ & $\begin{array}{c}\text { Energy value, } \\
\text { kcal per day }\end{array}$ \\
\hline 2005 & 71 & 96 & 368 & 2630 \\
\hline 2010 & 77 & 105 & 348 & 2652 \\
\hline 2017 & 80 & 108 & 338 & 2655 \\
\hline Rational norms & 82 & 95 & 417 & 2850 \\
\hline $\begin{array}{c}2017 \text { in 2005, } \\
\%\end{array}$ & 113 & 113 & 92 & 101 \\
\hline $\begin{array}{c}2017 \text { to } \\
\text { rational } \\
\text { standards, } \%\end{array}$ & 98 & 114 & 81 & 93 \\
\hline
\end{tabular}

Most of all meat, vegetables, sugar, vegetable oil is consumed in the USA, milk in Germany, eggs - Japan, potatoes and bread - Russia.

Despite the fact that consumption is approaching the recommended norms, the nutritional value of the existing diet can hardly be called satisfactory, the recommended norm has not been reached for proteins by $2 \%$, for carbohydrates by $19 \%$, and in general, by the energy value of calories per day by $7 \%$, and Exceeded the rate of fat intake by $14 \%$.

Table 8. International comparisons of the nutritional value of the prevailing per capita diet for 2013 according to the Food and Agriculture Organization

\begin{tabular}{|c|c|c|c|}
\hline Country & Protein & Fats & $\begin{array}{c}\text { Energy value, } \\
\text { kcal per day }\end{array}$ \\
\hline Russia & 103 & 106 & 3361 \\
\hline Germany & 102 & 142 & 3499 \\
\hline United Kingdom & 103 & 138 & 3424 \\
\hline France & 111 & 159 & 3482 \\
\hline USA & 110 & 162 & 3682 \\
\hline Japan & 88 & 87 & 2726 \\
\hline
\end{tabular}

According to the Food and Agriculture Organization, the energy value of the diet in Russia is lower than all countries except Japan, compared with the USA by $8.7 \%$, Germany $-3.9 \%$, France $-3.4 \%$, Great Britain $1.8 \%$.

Note, despite the improvement in nutrition, it remains low-calorie relative to the recommended norm. The mismatch between the excessive content of fat in food, potatoes, sugar and bread in the diet and the lack of calorie intake affects the health of the population of the Irkutsk region.

To fulfill the standards established by the Food Security Doctrine of the Russian Federation, taking into account the population stabilization plan, it is necessary to produce 1200 thousand tons of grain, 620 thousand tons of potatoes, 212 thousand tons of vegetables, 637 thousand tons of milk, 234 thousand tons of meat (calculations were made based on actual consumption). To achieve these indicators, a significant expansion of sown areas, an increase in the number of livestock, including cows, the construction of new complexes in animal husbandry and greenhouses, and the improvement of breeding and breeding work to increase the productivity of animals and arable land will be required $[9,10]$.

\section{Conclusion}

To reduce the dependence of the Irkutsk region on imports and ensure food security as one of the main priorities of socio-economic policy, the following tasks will be required:

- achieving the level of production of the main types of high-quality food products enough to provide the population of the Irkutsk region;

- improving the efficiency and competitiveness of agricultural commodity producers through technical and 
technological modernization of agricultural production with modern agricultural machinery, equipment and advanced technologies in crop production and animal husbandry;

- Creation of favorable socio-economic conditions for the development of rural areas.

\section{References}

1. A.I. Altukho, Providing the country with food under foreign sanctions, Bull. of the Kursk State Agricult. Acad., 9 (2014)

2. M.F. Tyapkina, T.S. Pukhmakhterova, S.I. Vinokurov, The Formation and Development of Integrated and Diversified Agro-Industrial Economic Structure JSC "Belorechenskoe", Econ. of agricult. and process. Enterpr., 1 (2018)

3. P.M. Pershukevich, Development of the agroindustrial complex of Siberia taking into account interstate food relations, Econ. of agricult. and process. enterpr., 3 (2011)

4. P.M. Pershukevich, L.V. Chu, Ensuring food security of the Siberian Federal Districts, Siber. Bull. of Agricult. Sci., 5(246) (2015)
5. A.S. Nechaev, D.V. Ognev, O.V. Antipina, Innovation risks: challenges and prospects, Advan. in Econ., Busin. and Manag. Res., 38 (2017)

6. N.I. Shagayda, A.M. Nikulin, V.Ya. Uzun, I.V. Trotsuk, E.A. Shishkin, Monitoring the state of food security in Russia in 2014-2016 (Institute of Applied Economic Research, RANEPA, 2018)

7. G.M. Vinokurov, M.V. Vinokurova, The state and prospects of crop production in the agricultural sector of the Irkutsk region, Econ. and manag.: probl., solut., 5 (2017)

8. V.I. Samarukh, Problems of development of agricultural production in the region, News of the Irkutsk State Econ. Acad., 5 (2008)

9. M.F. Tyapkina, E.A. Ilina, Assessment of the Reproduction Process of Agricultural Enterprises, Int. J. of ecolog. Econ. and statist., 39(1), 171-179 (2018)

10. I.G. Ushachev, N.A. Borkhunov, E.A. Sagaidak, V.V. Maslov, Economic problems of reproduction in the agricultural sector of Russia, in Encycloped. of Russ. Villages (2003) 